\title{
Blood and plasma titanium levels associated with well-functioning hip implants
}

Ilona Swiatkowska ${ }^{1}$, Nicholas G. Martin ${ }^{2}$, Johann Henckel $^{3}$, Hugh Apthorp ${ }^{4}$, Jane Hamshere $^{4}$, Alister J. Hart ${ }^{1,3}$

${ }^{1}$ Institute of Orthopaedics and Musculoskeletal Science, University College London, HA7 4LP Stanmore, UK

${ }^{2}$ Trace Element Laboratory, North West London Pathology, Charing Cross Hospital, W6 8RF London, UK

${ }^{3}$ Royal National Orthopaedic Hospital, Stanmore, HA7 4LP Stanmore, UK

${ }^{4}$ The Horder Centre, TN6 1XP Crowborough, UK

Correspondence and requests for materials should be addressed to I.S. (email:

ilona.swiatkowska.10@ucl.ac.uk, phone number: 0208416 3412)

\section{ABSTRACT}

Background: Hip implants are usually manufactured from cobalt-chromium and titanium

alloys. As the implants wear and corrode, metal debris is released into the surrounding tissue and blood, providing a potential biomarker for their function. Whilst there are laboratory reference levels for blood cobalt and chromium in patients with well and poorly functioning hip implants, there are no such guidelines for titanium. This is despite the increasing use of titanium implants worldwide.

Patients and methods: We recruited a consecutive series of 95 patients (mean age 71 years, mean time after surgery 8.5 years) with one hip implant type, inserted by the same surgeon. We assessed clinical and radiological outcome, and measured blood and plasma titanium using high resolution inductively-coupled plasma mass spectrometry.

Results: The upper normal reference limit for blood and plasma titanium was 2.20 and 2.56 $\mu \mathrm{g} \mathrm{L}{ }^{-1}$, respectively, and did not differ significantly between males and females.

Conclusion: We are the first to propose a laboratory reference level for blood and plasma titanium in patients with well-functioning titanium hip implants. This is an essential starting point for further studies to explore the clinical usefulness of blood titanium as a biomarker of orthopaedic implant performance, and comes at a time of considerable controversy regarding the use of certain titanium alloys in hip arthroplasty. 
Keywords: blood titanium; toxicity; TMZF; reference range; HR ICP-MS; total hip arthroplasty

\section{Introduction}

Components of joint replacements are usually manufactured from cobalt-chromium (Co-Cr) or titanium (Ti) alloys. Once implanted, all metals degrade through wear and corrosion, releasing ions and particles into the surrounding tissue and bloodstream. The greatest wear usually occurs during the first 1-2 years after surgery [1], which is followed by a low, but steady, rate of wear over subsequent years. The amount of metal debris released is a surrogate marker of implant wear [2], and can inform on the risk of local adverse effects and need for a revision surgery.

In the case of cobalt and chromium, a blood level of $2 \mu \mathrm{g} \mathrm{L}^{-1}$ implies a well-functioning metal-on-metal hip implant, while concentrations exceeding $7 \mu \mathrm{g} \mathrm{L}^{-1}$ indicate potential for local tissue damage and a failing implant [3]. It is now believed that measurement of titanium could also be used to gain insights into implant performance [4-7], though "normal" and "abnormal" blood levels have not been established. This is partly due to the technical challenges involved in the measurement of titanium in biological samples. Traditional techniques, such as graphite furnace atomic absorption spectroscopy (GF AAS) and quadrupole inductively-coupled plasma mass spectrometry, suffer from a range of interferences, which can lead to overestimation of analyte concentration. Several groups have reported blood/serum titanium levels associated with different types of well-functioning and malfunctioning prostheses [8]. However, in addition to unreliable analytical techniques used, majority of the studies suffered from small sample size.

We present a series of 95 patients with well-functioning, unilateral hip implants inserted by the same surgeon. We used a high resolution inductively-coupled plasma mass spectrometer 
(HR ICP-MS) to investigate how much titanium is released by the implants at medium-tolong term follow up (when the wear rate is thought to have normalised), and established a normal reference range for blood/plasma titanium in this population.

As uncemented hip replacements and 3D-printed implants are gaining popularity, the use of titanium in orthopaedics is growing. Additionally, constant ageing of the population means that the overall demand for total joint replacements is on the rise [9]. Taken together, these points underscore the potential impact of the present study. The proposed guidelines could be a useful tool to assess patients with titanium-based implants, and help predict which might develop clinical problems.

\section{Patients and methods}

This study protocol was approved by our institutional review board after ethical approval by Riverside Research Ethics Committee (ref. 07/Q0401/25).

All patients who received one type of titanium alloy femoral stem (see below for details) between 2007-2014 at a participating institution were identified using the National Joint Registry database $(\mathrm{N}=1036)$. Inclusion criteria stipulated unilateral, primary, uncemented ceramic-on-ceramic $(\mathrm{CoC})$ hip implants inserted by the same surgeon. All eligible participants $(\mathrm{N}=199)$ were invited, and those willing to take part were booked in for a clinic visit. The assessment involved 1) a pelvis X-ray; 2) Oxford Hip Score; 3) UCLA Activity Score, 4) a blood test and 5) a short interview. A complete set of data was obtained for 95 subjects (42 males and 53 females) (Figure 1). The underlying diagnoses leading to the primary surgery were osteoarthritis $(98 \%)$ or developmental hip dysplasia $(2 \%)$.

All patients provided written informed consent to participate in the study. 


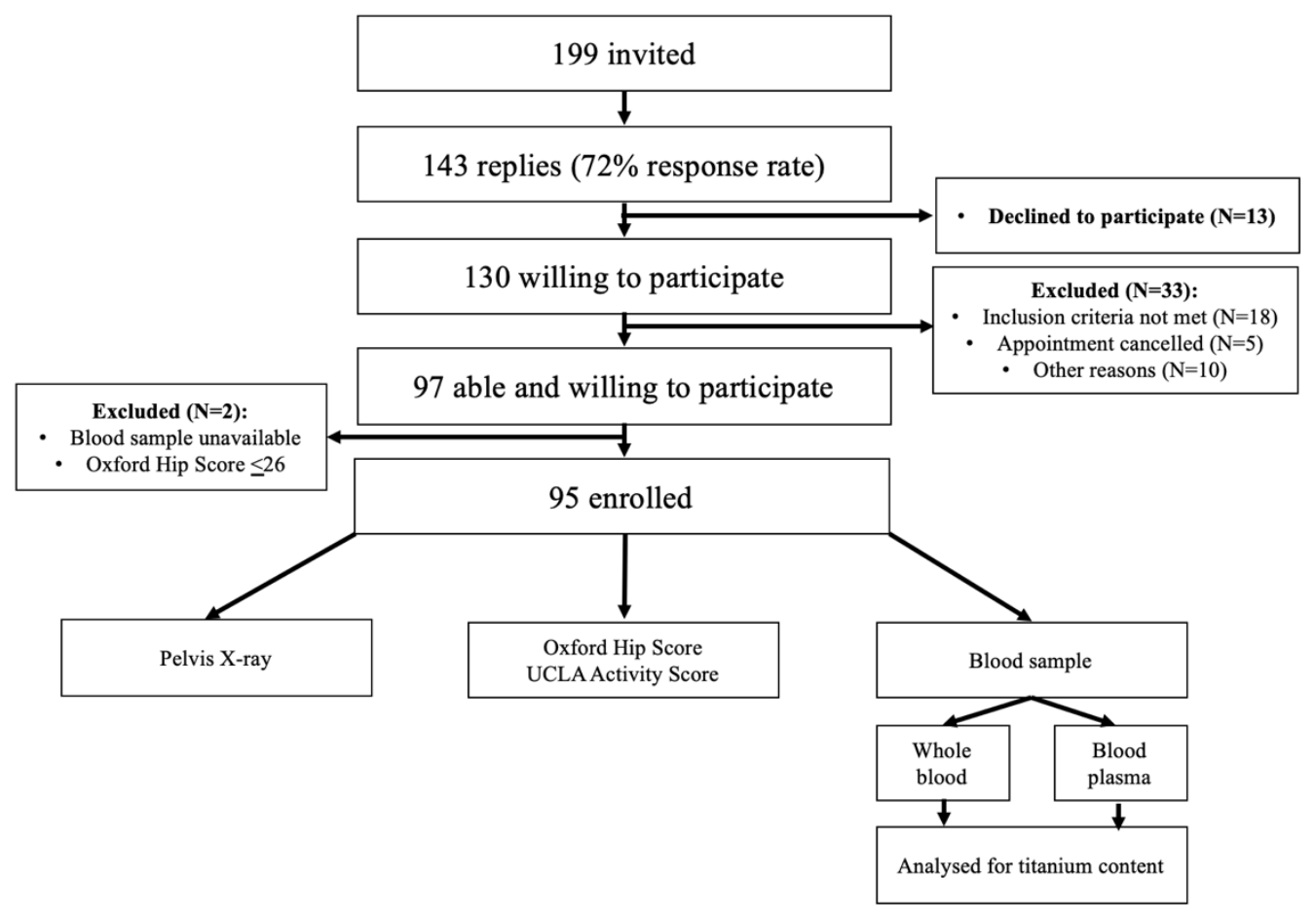

Figure 1. Flowchart outlining participant enrolment and clinical assessment.

\subsection{Implants}

Implant design was uniform across the series, and comprised a V40 $32 \mathrm{~mm} \mathrm{Al}_{2} \mathrm{O}_{3}$ (alumina) femoral head articulating against a Trident ${ }^{\circledR}$ titanium-backed alumina insert, a commercially pure titanium Trident ${ }^{\circledR}$ PSL acetabular cup and a Ti-12Mo-6Zr-2Fe (TMZF) Accolade $®$ I

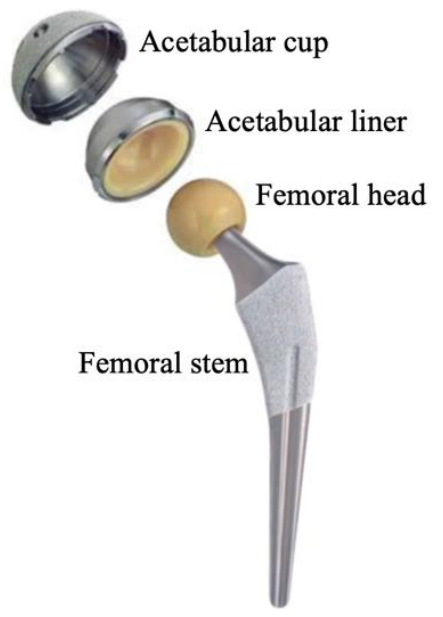

Figure 2. The implant design featured in the current study. femoral stem (Figure 2). All the components were manufactured by Stryker Orthopaedics (Mahwah, NJ) and were inserted without cement. In several cases, the acetabular component was secured to the pelvis with a varying number of titanium alloy (Ti-6Al-4V) screws. $11(12 \%)$ participants had cobalt-chromium-molybdenum (CoCrMo) alloy knee replacement implants in addition to the hip implant. Since these did not contain titanium, they were included in the study. 
Despite good clinical performance and overall high success rate [10], the TMZF Accolade stem was reported to fail when combined with large diameter $(\geq 36 \mathrm{~mm}) \mathrm{Co}-\mathrm{Cr}$ femoral heads $[11,12]$. Even though similar problems were not observed with ceramic [13] or smaller Co-Cr alloy femoral heads, in 2012 the design was replaced with Accolade II stem made of standard Ti-6Al-4V alloy.

\subsection{Radiographs}

Standardized anteroposterior radiographs were taken on a Proteus X-ray machine (GE Healthcare). The films were pseudonymised and reviewed by two observers for evidence of poor implant positioning, signs of acetabular cup/femoral stem loosening and adverse reaction to metal (ARMD), such as pseudotumours and tissue necrosis. Factors, such as acetabular cup abduction/anteversion angle and femoral offset, were found not to influence blood titanium levels $[14,15]$, so they were not quantified in the current study.

\subsection{Blood sample collection and analysis}

Blood samples were withdrawn from a forearm vein using a stainless-steel needle surrounded by an inert plastic cannula. As a precautionary measure, the first $5 \mathrm{~mL}$ of blood drawn was used to rinse the system and then discarded. The subsequent $5 \mathrm{~mL}$ of blood were collected into Vacuette ${ }^{\circledR}$ Trace Elements tubes (Greiner Bio-One International) coated with sodium heparin as anticoagulant. The specimens were shipped to the Trace Elements Laboratory at the Charing Cross Hospital on the same day, where they were mixed by inversion and $2.5 \mathrm{~mL}$ of whole blood was aliquoted. The remaining $2.5 \mathrm{~mL}$ of blood was centrifuged at $2500 \mathrm{rpm}$ in a bench-top centrifuge for 10 minutes, to separate the plasma. The samples were refrigerated at $4^{\circ} \mathrm{C}$ prior to analysis. 
Whole blood and plasma samples were analysed separately for titanium content on a Thermo Element 2 HR ICP-MS instrument (Thermo Fisher Scientific GmBH, Bremen, Germany), with an estimated limit of detection (LoD) of $0.77 \mu \mathrm{g} \mathrm{L}^{-1}$ for titanium (calculated as $3 \mathrm{x}$ the standard deviation of the blank concentrations [16]). Two levels of ClinChek Plasma (Recipe, Germany) Internal Quality Control (IQC) and two levels of Custom Whole Blood IQC (UTAK, US) material were included in each batch (see Table A.1 for the IQC results). The laboratory was enrolled in the Quebec Multielement External Quality Assessment Scheme at the time this study was carried out (see Table A.2 for the results). $150 \mu \mathrm{L}$ of each sample or IQC were dispensed into polystyrene assay tubes with $150 \mu \mathrm{L}$ of water and $4.5 \mathrm{~mL}$ of assay diluent $(0.5 \%(\mathrm{v} / \mathrm{v})$ tetramethylammonium hydroxide (Electronics grade, Alpha Aesar, US), $0.005 \%$ (v/v) Triton X-100 (Romil, UK)) and $2.5 \mu \mathrm{g} / \mathrm{L}$ gallium (Alpha Aesar, US). Calibration standards were prepared by dilution from a custom stock solution (Qmx Laboratories Limited, Thaxted, UK) with a titanium concentration traceable to NIST SRM 3162a Lot 130925. The standard concentrations were: $0.00 \mu \mathrm{g} / \mathrm{L}, 1.00 \mu \mathrm{g} / \mathrm{L}, 4.00$ $\mu \mathrm{g} / \mathrm{L}, 9.99 \mu \mathrm{g} / \mathrm{L}, 39.96 \mu \mathrm{g} / \mathrm{L}, 99.90 \mu \mathrm{g} / \mathrm{L}$ and $249.75 \mu \mathrm{g} \mathrm{L} \mathrm{L}^{-1}$. Whole blood and serum/plasma matrix matched calibrations were prepared by dispensing $150 \mu \mathrm{L}$ of each standard into polystyrene assay tubes with $4.5 \mathrm{~mL}$ of assay diluent and $150 \mu \mathrm{L}$ and either Defibrinated Horse Blood (TSC Biosciences, Buckingham, UK) or Foetal Bovine Serum (Sigma-Aldrich, UK). The diluted samples, calibration standards and IQCs were sequentially sampled using an ESI-SC FAST autosampler (Elemental Scientific, US) and introduced to the HR ICP-MS with a PTFE Nebulizer (Elemental Scientific, US) and cyclonic spray chamber (Thermo Scientific). See Table A.3 for the ICP-MS settings used for each element. The counts per second (cps) data for $\mathrm{Ti}^{47} \mathrm{cps}$ were normalised to $\mathrm{Ga}^{71} \mathrm{cps}$ and a calibration curve was plotted using ordinary linear regression in Microsoft Excel. The regression equation was then applied to the normalised $\mathrm{Ti}^{47} \mathrm{cps}$ for each sample and IQC to give the Ti concentration. 


\subsection{Other outcome measures}

The participants were asked to complete an Oxford Hip Score (OHS) to assess pain and function of the hip in relation to daily activities [17]. The questionnaire consists of 12 questions scored from 0 (worst outcome) to 4 (best outcome), with overall scores running from 0 to 48. It this scoring system, a total score $\geq 42$ is considered excellent, 41-34 good, 3327 fair and $\leq 26$ poor [18]. Participants with excellent and good implant function $(\geq 34)$ were included in the present study, while those with poor scores $(\leq 26)$ were excluded. The OHS is short, reproducible and sensitive to clinically important changes, and therefore widely used to assess hip function and pain in THA patients [19]. However, since it was designed as a sitespecific outcome measure, patients can find it hard to discriminate between pain/disability from the replaced joint and that arising from an existing co-morbidity (such as arthritis in other joints) [20]. For this reason, participants with fair scores (33-27), who volunteered the existence of a co-morbidity affecting the score, were also included in the study.

Since increased physical activity has the potential to accelerate implant wear and raise blood metal levels [21], the participants were classified using the University of California Los Angeles (UCLA) Activity Score (Figure 3) .

\begin{tabular}{|c|c|}
\hline Level & Activity \\
\hline 10 & $\begin{array}{l}\text { Regularly participate in impact sports such as jogging, } \\
\text { tennis, skiing, acrobatics, ballet, heavy labor, or } \\
\text { backpacking }\end{array}$ \\
\hline 9 & Sometimes participate in impact sports \\
\hline 8 & $\begin{array}{l}\text { Regularly participate in very active events, such as } \\
\text { bowling or golf }\end{array}$ \\
\hline 7 & Regularly participate in active events, such as bicycling \\
\hline 6 & $\begin{array}{l}\text { Regularly participate in moderate activities, such as } \\
\text { swimming and unlimited housework or shopping }\end{array}$ \\
\hline 5 & Sometimes participate in moderate activities \\
\hline 4 & $\begin{array}{l}\text { Regularly participate in mild activities, such as walking, } \\
\text { limited housework, and limited shopping }\end{array}$ \\
\hline 3 & Sometimes participate in mild activities \\
\hline 2 & $\begin{array}{l}\text { Mostly inactive: restricted to minimal activities of daily } \\
\text { living }\end{array}$ \\
\hline 1 & $\begin{array}{l}\text { Wholly inactive: dependent on others; cannot leave } \\
\text { residence }\end{array}$ \\
\hline
\end{tabular}

Figure 3. UCLA activity level rating. 


\subsection{Statistical analyses}

The Shapiro-Wilk test revealed that age was the only normally-distributed variable in the dataset. Blood and plasma titanium, OHS and activity scores followed a skewed distribution, and were analysed with non-parametric tests. Gender differences were assessed using the independent samples t-test or the Mann-Whitney test, while the influence of age, implant time in situ, OHS and activity level on titanium levels was assessed with Pearson's correlation method. The same method was used to correlate the titanium content of blood and plasma. SPSS (version 25) was employed for all statistical analyses, with p values $<0.05$ considered statistically significant.

\section{Results}

The demographic data and study results are summarised in Table $\mathbf{1 .}$

Table 1. Patient demographics and summary of study results.

\begin{tabular}{|c|c|c|c|c|}
\hline & Male $(n=42)$ & Female $(n=53)$ & Overall $(n=95)$ & Gender difference? \\
\hline \multicolumn{5}{|c|}{ Age } \\
\hline Mean & 72 & 71 & 71 & No $(p=0.44)$ \\
\hline Median & 73 & 71 & 71 & \\
\hline SD & 8 & 6 & 7 & \\
\hline Range & $54-87$ & $53-84$ & $53-87$ & \\
\hline IQR & $66-77$ & $67-75$ & $67-76$ & \\
\hline \multicolumn{5}{|c|}{ Implant time in situ (months) } \\
\hline Mean & 95 & 107 & 101 & \\
\hline Median & 92 & 107 & 102 & Yes $(p=0.009)$ \\
\hline
\end{tabular}




\begin{tabular}{|c|c|c|c|c|}
\hline SD & 21 & 20 & 21 & \\
\hline Range & $64-142$ & $64-143$ & $64-143$ & \\
\hline IQR & $81-111$ & $90-121$ & $86-118$ & \\
\hline \multicolumn{5}{|c|}{ Oxford Hip Score ( 48 being the best possible score) } \\
\hline Mean & 45 & 45 & 45 & \\
\hline Median & 46 & 47 & 47 & No $(p=0.22)$ \\
\hline SD & 4 & 4 & 4 & \\
\hline Range & $32-48$ & $28-48$ & $28-48$ & \\
\hline IQR & $43-48$ & $45-48$ & $45-48$ & \\
\hline \multicolumn{5}{|c|}{ UCLA Activity Score (10 being the most physically active) } \\
\hline Mean & 6 & 6 & 6 & \\
\hline Median & 7 & 6 & 6 & No $(p=0.21)$ \\
\hline SD & 2 & 1 & 2 & \\
\hline Range & $2-10$ & $3-10$ & $2-10$ & \\
\hline IQR & $5-8$ & $6-7$ & $6-8$ & \\
\hline \multicolumn{5}{|c|}{ Blood Ti $\left(\mu \mathrm{g} \mathrm{L}^{-1}\right)$} \\
\hline Mean & 1.32 & 1.38 & 1.35 & \\
\hline Median & 1.20 & 1.20 & 1.20 & No $(p=0.69)$ \\
\hline SD & 0.39 & 0.56 & 0.49 & \\
\hline Range & $0.8-2.3$ & $0.6-4.4$ & $0.6-4.4$ & \\
\hline IQR & $1.0-1.5$ & $1.1-1.6$ & $1.0-1.5$ & \\
\hline \multicolumn{5}{|c|}{ Plasma Ti $\left(\mu g L^{-1}\right)$} \\
\hline Mean & 1.74 & 1.93 & 1.85 & \\
\hline Median & 1.70 & 1.70 & 1.70 & No $(p=0.36)$ \\
\hline
\end{tabular}




\begin{tabular}{|c|c|c|c|c|}
\hline SD & 0.50 & 1.03 & 0.84 & \\
\hline Range & $0.7-3.1$ & $0.7-8.6$ & $0.7-8.6$ & \\
\hline IQR & $1.4-2.1$ & $1.6-2.2$ & $1.4-2.1$ & \\
\hline
\end{tabular}

$S D$ - standard deviation, IQR- interquartile range.

\subsection{Trace metal analysis}

Blood and plasma titanium levels followed a skewed distribution, with one outlier (a value larger than 3 IQR from the $75^{\text {th }}$ percentile) which was included in the statistical analyses (Figure 4). 

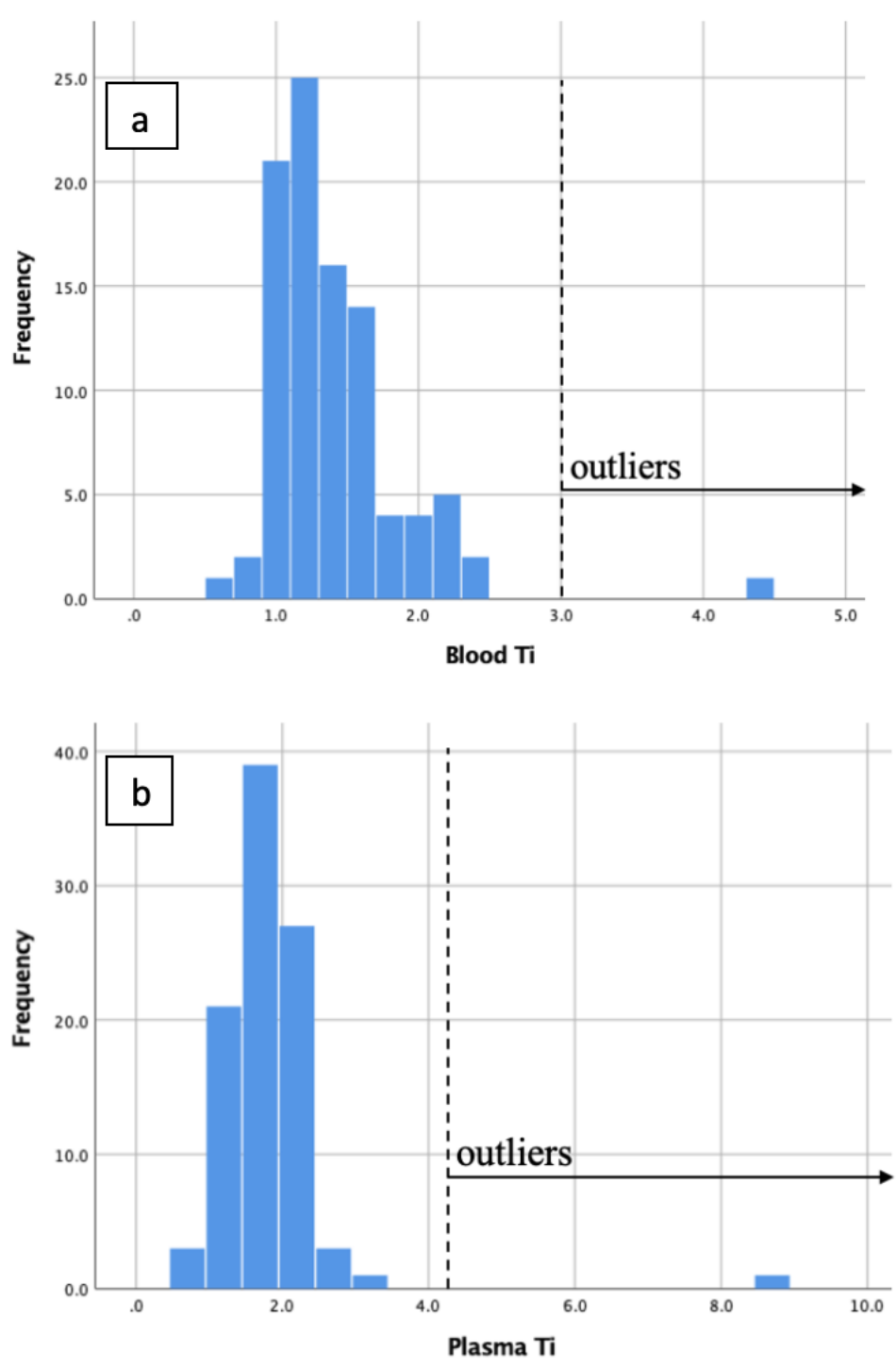

Figure 4. Histograms showing the spread of a) blood and b) plasma titanium measurements, with the $75^{\text {th }}$ percentile+3IQR level marked.

The median blood and plasma titanium were $1.2 \mu \mathrm{g} \mathrm{L} \mathrm{L}^{-1}$ (IQR 1.0-1.5) and $1.7 \mu \mathrm{g} \mathrm{L}^{-1}$ (IQR 1.4-2.1), with the upper normal level (95 ${ }^{\text {th }}$ percentile) of 2.20 and $2.56 \mu \mathrm{g} \mathrm{L} \mathrm{L}^{-1}$, respectively. There was a moderately strong correlation between titanium level in the blood and in the plasma $\left(\mathrm{r}_{\mathrm{s}}=0.571 ; \mathrm{p}<0.0001\right)($ Figure 5), which remained statistically significant even after the outlier had been excluded from analysis $\left(r_{s}=0.557 ; p<0.0001 ; R^{2}=0.287\right)$. Even though there was a significant difference in follow-up time between males and females, blood and plasma titanium did not differ between the groups (Figure 6). Moreover, no significant 
correlations between blood titanium values and age $(\mathrm{r}=0.056 ; \mathrm{p}=0.59)$, implant months in situ $\left(\mathrm{r}_{\mathrm{s}}=-0.151 ; \mathrm{p}=0.14\right)$, OHS $\left(\mathrm{r}_{\mathrm{s}}=-0.01 ; \mathrm{p}=0.92\right)$ or activity score $\left(\mathrm{r}_{\mathrm{s}}=-0.012 ; \mathrm{p}=0.91\right)$ were detected. Similarly, there were no significant correlations between plasma titanium values and age $(\mathrm{r}=0.052 ; \mathrm{p}=0.61)$, OHS $\left(\mathrm{r}_{\mathrm{s}}=-0.058 ; \mathrm{p}=0.58\right)$ and activity score $\left(\mathrm{r}_{\mathrm{s}}=-0.033 ; \mathrm{p}=0.75\right)$. We detected a weak negative association between plasma titanium and implant years in situ $\left(\mathrm{r}_{\mathrm{s}}=-0.313 ; \mathrm{p}=0.002\right)$

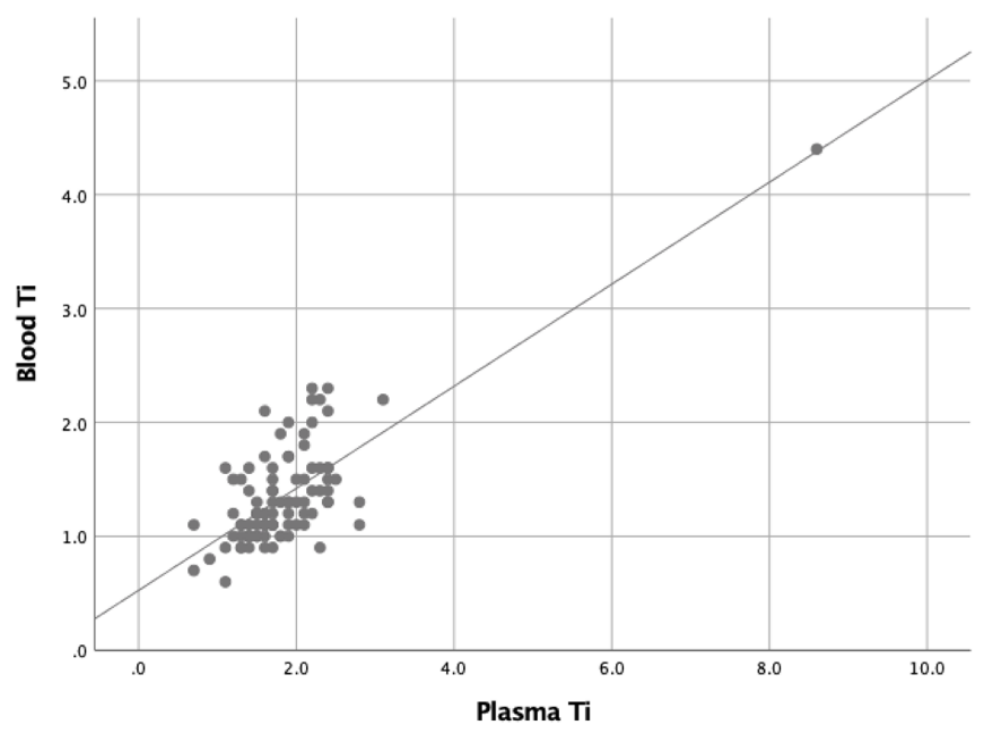

Figure 5. Scatter plot of plasma versus blood titanium, showing a statistically significant positive correlation between the two $\left(R^{2}=0.583 ; p<0.0001\right)$.

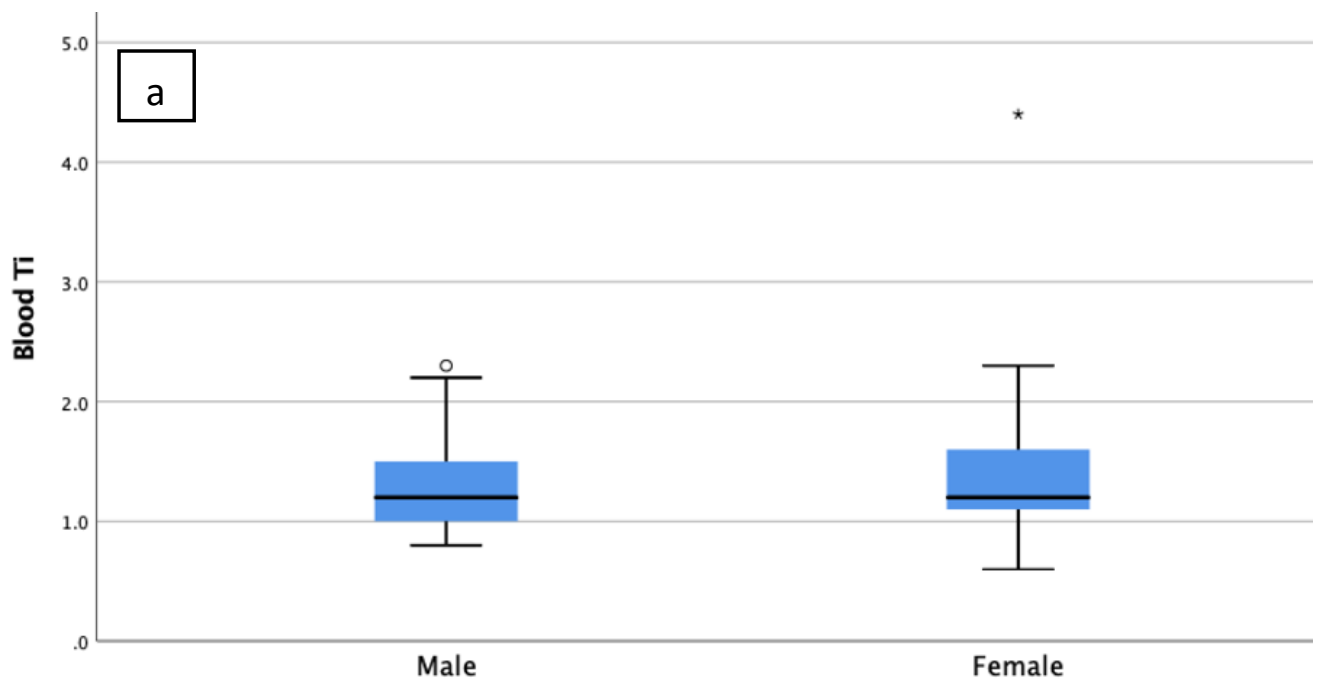




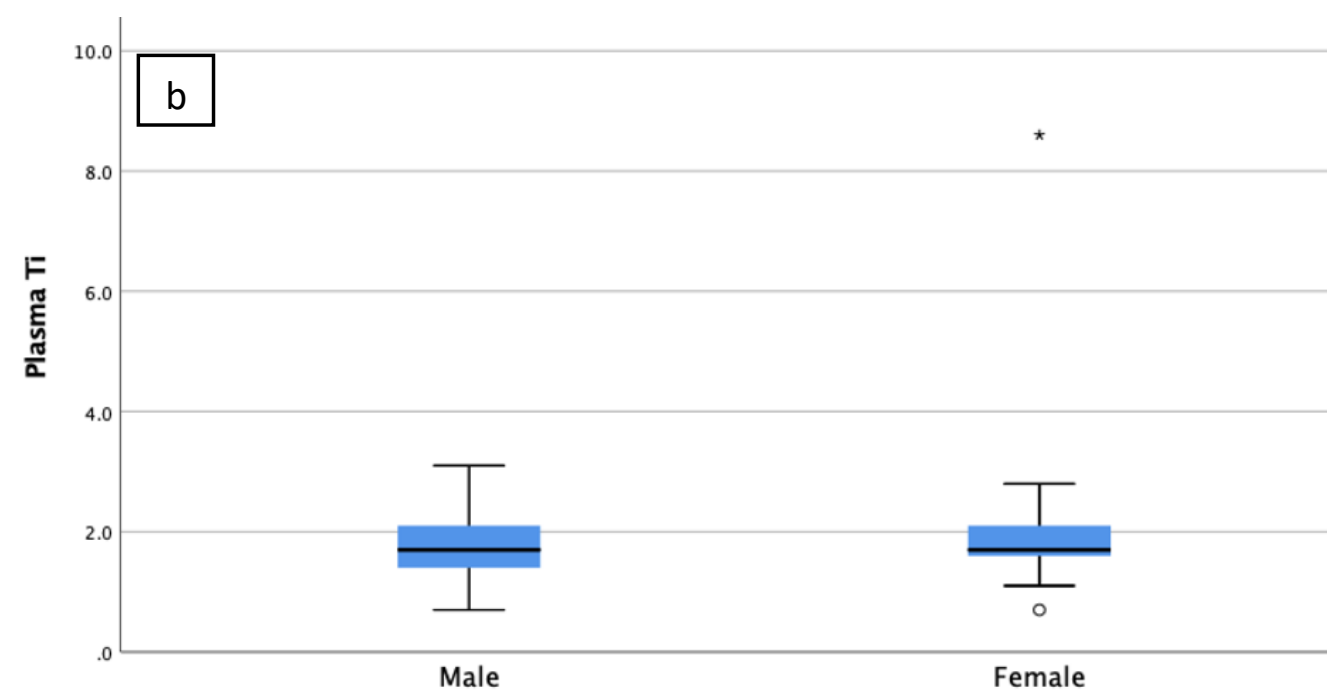

Figure 6. Box plots of titanium concentration in a) blood and b) plasma of study participants. The boundaries of the box represent the $25^{\text {th }}$ and $75^{\text {th }}$ percentile, with the median line inside the box. The whiskers extend to maximum and minimum values in each data set. Outliers (values more than 1.5xIQR from the end of the box) are identified as open circles, while extreme outliers (values more than 3xIQR from the end of the box) are denoted as asterisks.

\subsection{Radiographs}

All the hip implants were well-positioned, with no signs of cup loosening or gross soft tissue changes evident from the radiographs (Figure 7). Two femoral stems (2\%) were radiologically loose, but clinically asymptomatic (Figure 8).

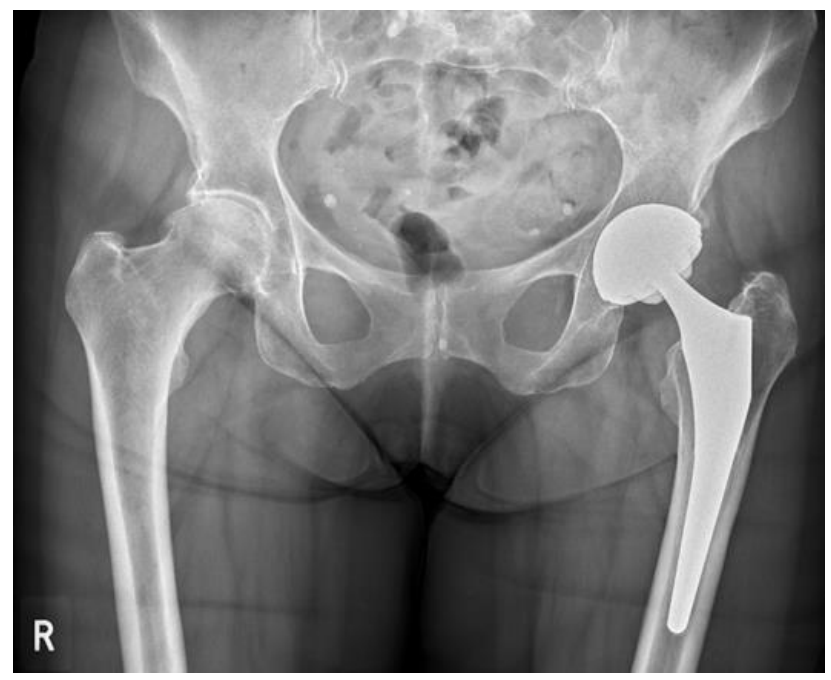

Figure 7. A representative anteroposterior radiograph from the current series, showing a well-fixed hip implant. 


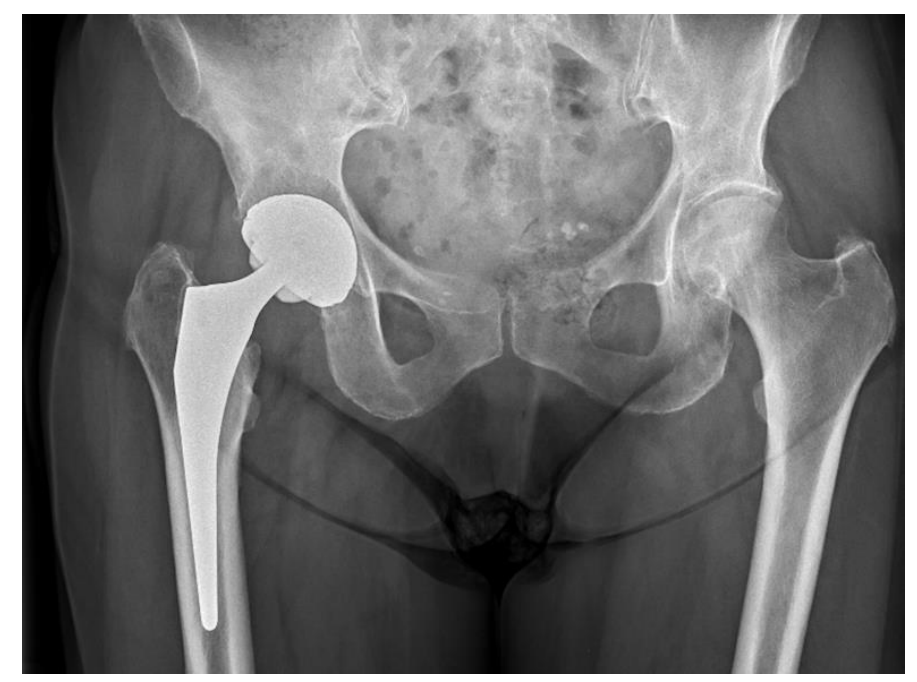

Figure 8. Radiologically loose stem.

\subsection{Oxford Hip Score}

$84(88 \%)$ patients had excellent hip function and $8(8 \%)$ had good hip function. The remaining 3 patients with fair function reported that the lower scores were due to severe arthritis in other joints or spinal stenosis. One patient with unexplained pain in the replaced hip, and an OHS score of 16, was excluded from the study.

\section{Discussion and conclusions}

This study proposes laboratory threshold values for blood $\left(2.20 \mu \mathrm{g} \mathrm{L}^{-1}\right)$ and plasma $(2.56 \mu \mathrm{g}$ $\mathrm{L}^{-1}$ ) titanium in patients with well-functioning titanium hip implants at medium-to-long term follow up. These guidelines are an essential starting point for further studies to explore the clinical usefulness of blood titanium as a biomarker of orthopaedic implant performance, and come at a time of considerable controversy regarding the use of certain titanium alloys in hip arthroplasty.

Compared to cobalt and chromium, relatively little research has been directed to the biological effects of titanium ions and, unlike for blood cobalt and chromium, a "cut-off" value has not been defined for titanium. The current Mayo Clinic Laboratory guidelines state 
that a prosthetic device in good condition should give rise to serum titanium in the range of 1$3 \mu \mathrm{g} \mathrm{L}^{-1}$, while concentrations exceeding $10 \mu \mathrm{g} \mathrm{L}^{-1}$ indicate prosthesis wear. These values are based on the 1998 works by Jacobs and Liu. Jacobs et al. [22] used GF AAS to quantify serum titanium in 55 patients with 3 different types of well-functioning hip implants, while Liu et al. [23] measured blood titanium associated with well-fixed (5 patients) and loose (4 patients) knee prostheses. More recently, Jacobs et al. [4] proposed that well-functioning, unilateral hip implants should produce serum titanium levels of approximately $4 \mu \mathrm{g} \mathrm{L}^{-1}$, while levels exceeding $8 \mu \mathrm{g} \mathrm{L}^{-1}$ should warrant further investigation. Savarino et al. found that the upper normal reference limit was $5.13 \mu \mathrm{g} \mathrm{L}^{-1}$ in the medium term (2-7-year follow up) [24], and $4.5 \mu \mathrm{g} \mathrm{L}^{-1}$ in the long term (10-year follow up) [25]. It is important to note that all of the above studies employed GF AAS for trace metal analysis, which is, as is now known, not sensitive/selective enough to measure titanium accurately [26]. The instrumental LoD quoted in the Savarino study $\left(2.91 \mu \mathrm{g} \mathrm{L}^{-1}\right)$ was likely not low enough to appreciate the subtle titanium elevations in patients with well-functioning prostheses. Studies employing HR ICPMS point to lower values, which generally decrease with increasing length of follow up (Table 2). Discrepancies between "normal" serum levels measured by GF AAS and the more powerful HR ICP-MS were previously observed for aluminium, where the latter technique obtained values one order of magnitude lower than those published before using GF AAS [27]. 
1 Table 2. Blood and serum titanium levels associated with different types of well-functioning titanium-based hip implants.

\begin{tabular}{|c|c|c|c|c|c|c|}
\hline Ref & Analytical technique & $\operatorname{LoD}\left(\mu g L^{-1}\right)$ & Blood Ti $\left(\mu \mathrm{g} \mathrm{L}^{-1}\right)^{\mathrm{a}}$ & Serum Ti $\left(\mu \mathrm{g} \mathrm{L}^{-1}\right)^{\mathrm{a}}$ & Implant fixation/ function assessment & Follow up \\
\hline [26] & HR ICP-MS & 1.1 & $\begin{array}{l}2.306(\mathrm{n}=11) \\
1.519(\mathrm{n}=11)\end{array}$ & $\begin{array}{l}\mathrm{n} / \mathrm{a} \\
\mathrm{n} / \mathrm{a}\end{array}$ & Not assessed & $\begin{array}{l}\text { 14-22 months } \\
\text { 70-106 months }\end{array}$ \\
\hline [28] & HR ICP-MS & 0.05 & $\begin{array}{l}3.0(\mathrm{n}=9 \text { males }) \\
2.2(\mathrm{n}=6 \text { females })\end{array}$ & $\begin{array}{l}\mathrm{n} / \mathrm{a} \\
\mathrm{n} / \mathrm{a}\end{array}$ & Not assessed & $\begin{array}{l}\mathrm{n} / \mathrm{a} \\
\mathrm{n} / \mathrm{a}\end{array}$ \\
\hline [29] & HR ICP-MS & $<0.1$ & $\begin{array}{l}3.74 ; 1.40-8.80(\mathrm{n}=34) \\
2.75 ; 1.40-4.10(\mathrm{n}=33) \\
1.83 ; 0.90-4.60(\mathrm{n}=31) \\
1.30 ; 0.35-2.40(\mathrm{n}=24)\end{array}$ & $\begin{array}{l}\mathrm{n} / \mathrm{a} \\
\mathrm{n} / \mathrm{a} \\
\mathrm{n} / \mathrm{a} \\
\mathrm{n} / \mathrm{a}\end{array}$ & $\begin{array}{l}\text { X-Ray/ WOMAC, Merle D'Aubigne and } \\
\text { Postel scores }\end{array}$ & $\begin{array}{l}3 \text { months } \\
6 \text { months } \\
1 \text { years } \\
2 \text { years }\end{array}$ \\
\hline$[30]$ & HR ICP-MS & $<0.1$ & $\mathrm{n} / \mathrm{a}$ & $2.7 ; 1.1-7.0(\mathrm{n}=6)$ & Not assessed & 7-13 months \\
\hline [31] & HR ICP-MS & 0.2 & $\mathrm{n} / \mathrm{a}$ & $1.8 ; 1.7-1.9(\mathrm{n}=8)$ & X-Ray/ Harris Hip Score & 10 years \\
\hline [32] & HR ICP-MS & $<0.17$ & $\begin{array}{l}\mathrm{n} / \mathrm{a} \\
\mathrm{n} / \mathrm{a}\end{array}$ & $\begin{array}{l}2.54 ; 2.17-3.10(\mathrm{n}=23) \\
2.70 ; 2.11-3.25(\mathrm{n}=23)\end{array}$ & Not assessed & $\begin{array}{l}1 \text { years } \\
2 \text { years }\end{array}$ \\
\hline [33] & HR ICP-MS & $<0.4$ & $\begin{array}{l}2.165(\mathrm{n}=15) \\
1.359(\mathrm{n}=15) \\
2.160(\mathrm{n}=15)\end{array}$ & $\begin{array}{l}\mathrm{n} / \mathrm{a} \\
\mathrm{n} / \mathrm{a} \\
\mathrm{n} / \mathrm{a}\end{array}$ & $\begin{array}{l}\text { X-ray/ Short-Form 12, WOMAC, Harris } \\
\text { Hip Score }\end{array}$ & $\begin{array}{l}1 \text { years } \\
2 \text { years } \\
5 \text { years }\end{array}$ \\
\hline [14] & HR ICP-MS & $<2.0$ & $\mathrm{n} / \mathrm{a}$ & $2.28(\mathrm{n}=74)$ & X-ray/ WOMAC, Harris Hip Score & 50 months \\
\hline
\end{tabular}

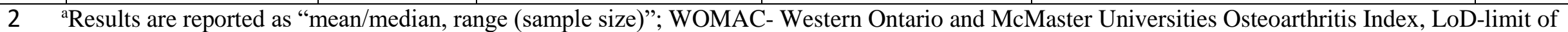
3 detection. 


\section{4.1. Comparison with other studies using HR ICP-MS}

5 The mean titanium level in the current series was $1.35 \mu \mathrm{g} \mathrm{L}^{-1}$ in whole blood and $1.85 \mu \mathrm{g} \mathrm{L}{ }^{-1}$

6 in the plasma, at a mean follow up of 8.5 years (range 5-12). This is consistent with the work

7 of Sarmiento-Gonzalez et al. [26], who investigated 11 patients with titanium-based hip

8 implants, and reported a mean blood level of $1.52 \mu \mathrm{g} \mathrm{L}-1$ at a mean 6.5 years after surgery

9 (range 6-9). Levine et al. [31], who measured serum titanium in 8 patients with well-

10 functioning (confirmed with X-rays and Harris Hip Score) metal-on-polyethylene

11 implants, noted that the levels peaked at 3 years and then proceeded to decline until after the

9-year interval. Mean serum titanium at 9-year follow up reported by the authors was approximately $1.8 \mu \mathrm{g} \mathrm{L}^{-1}$, which is in very close agreement with our findings. The decreasing trend in plasma titanium over time was also apparent in the present study, and could mean that the rate of implant degradation decreases, or that the efficiency with which titanium ions are excreted improves, with increasing implant time in situ. However, the most likely explanation is that the metal is slowly accumulated in systemic tissue [34]. The clinical implications of titanium deposition, and chronic low-level exposure to titanium ions, are yet to be established. While titanium is considered to be less toxic than cobalt and chromium, the issue of titanium sensitivity/allergy is still under discussion [35]. It has been suggested that those with a pre-operative sensitivity to titanium might be at an increased risk of local adverse reactions to titanium debris [36]. Titanium levels were not influenced by age, gender or OHS, which was expected, since all the implants displayed excellent or good function. Titanium measurements were not correlated with activity level either. Vendittoli et al. [29] was also unable to find a significant correlation between UCLA Activity Score and post-operative blood titanium level at 1-2-

27 year follow up. Taken together, these findings suggest that increased physical activity does not influence the magnitude of titanium release from hip implants. Titanium is not part of the 
bearing surface, and its release is thought to occur via passive corrosion of the acetabular cup and/or the femoral stem, rather than through wear [32]. Corrosion, unlike wear, is unlikely to be affected by physical activity, which helps to explain our findings.

\subsection{Whole blood versus plasma/serum sampling}

Titanium ions associate with plasma proteins [37], which accounts for the higher titanium content of plasma compared to whole blood [38]. Serum/plasma sampling is preferred by some researchers, because the higher titanium levels are easier to detect and quantify. The official Medicines and Healthcare products Regulatory Agency (MHRA) guidelines call for the measurement of cobalt and chromium in whole blood, but it is still unclear which blood fraction is optimal for monitoring titanium levels in THA patients. Based on our experience, we recommend analysis of whole blood when a high resolution instrument with a low LoD is employed. The extra processing steps required for serum/plasma separation might introduce contaminants into the sample and have a devastating effect on the results of trace element assays, particularly when minute titanium concentrations are being measured [39].

\subsection{Study strengths}

The main strengths of our investigation lie in the clean data set we obtained and the state-ofthe art analytical technique we employed for trace metal analysis. All the participants received the same implant and were operated on by the same team, thus removing surgical variability. Our study also boasts a large sample size, which enabled us to obtain accurate estimates of "normal" titanium levels in THA patients. Correct implant placement and fixation were evaluated radiologically, while good clinical function was ensured with excellent or good OHS, which was not always done in previous studies. The X-rays and questionnaires were taken on the same day as the blood samples to make sure that the trace 
metal analysis was as meaningful as possible. The analytical approach we employed is considered to be one of the most effective for the determination of titanium in biological fluids [31]. HR ICP-MS boasts a short run time, low LoD (1-3 orders of magnitude lower than GF AAS $[40,41])$ and is able to measure multiple elements/isotopes simultaneously, making it possible to analyse a large number of samples quickly and reliably. Our results are in close agreement with previous smaller studies that used the same technique to determine blood/serum titanium in THA patients with well-functioning implants [26,31].

\subsection{Study limitations}

The present study has a number of limitations. First, pre-operative blood titanium measurements were unavailable, so that true influence of the hip implant on the systemic titanium load could not be assessed. As blood/serum titanium level in patients without orthopaedic implants is thought to be lower than $1 \mu \mathrm{g} \mathrm{L}^{-1}[8]$, the values observed in the current series are considered to be mildly elevated. While we believe that the main source of raised metal levels was the hip implant, it is likely that external sources contributed to it. Titanium dioxide $\left(\mathrm{TiO}_{2}\right)$ is added in varying levels to many foodstuffs and personal care products [42], as well as being present in ambient air. HR ICP-MS quantifies both ionic and particulate titanium [43], and is unable to discriminate between the two forms of the metal. None of the participants disclosed occupational exposure to titanium, but dietary intake, and the use of titanium-containing products, were impossible to control for. Secondly, recent creatinine clearance data was unavailable, so we could not estimate the participants' renal function (impaired excretion could lead to increased retention of metals in the body [27]). Titanium is highly insoluble and tends to accumulate in tissue, with only a small fraction excreted in the urine $[44,45]$. It follows that kidney function is unlikely to influence the systemic titanium load to a great extent. 


\subsection{Clinical significance}

81 The use of titanium in THA is increasing, and there is a renewed interest in blood titanium as

82 a biomarker of implant wear. In particular, it is thought that elevated blood levels could help

83 identify malfunctioning prostheses before they fail $[4,5,7]$, though the normal "cut-off" value to guide diagnosis of malfunctioning implants has not been well-defined. We aimed to bridge this data gap with the present study, which is the largest investigation of systemic titanium levels associated with well-functioning titanium-based implants to date. Future work in this area should involve applying our guidelines $\left(2.20 \mu \mathrm{g} \mathrm{L}^{-1}\right.$ for blood and $2.56 \mu \mathrm{g} \mathrm{L}^{-1}$ for plasma titanium) to other patients, and looking for radiographic signs of ARMD, implant loosening and wear. This approach could be a means of monitoring the tens of thousands of patients with titanium-based hips, and could help predict which might develop clinical problems.

\section{Acknowledgments}

The authors would like to thank The Horder Centre for their invaluable support and assistance, with a special thank you to the radiology and phlebotomy teams, and Ms Tracy Young.

\section{$97 \quad$ Funding}

This work was supported by Gwen Fish Orthopaedic Trust and The Horder Centre. The funding sources did not have involvement in the analysis and interpretation of data, in the writing of the report or in the decision to submit the article for publication.

\section{References}

103 [1] O. Posada, R. Tate, R.M. Meek, M. Grant, In vitro analyses of the toxicity, immunological, and gene expression effects of cobalt-chromium alloy wear debris and 
Co ions derived from metal-on-metal hip implants, Lubricants. 3 (2015) 539-568.

[2] B. Sampson, A. Hart, Clinical usefulness of blood metal measurements to assess the failure of metal-on-metal hip implants., Ann. Clin. Biochem. 49 (2012) 118-31. doi:10.1258/acb.2011.011141.

[3] A.J. Hart, S.A. Sabah, A.S. Bandi, P. Maggiore, P. Tarassoli, B. Sampson, J. A. Skinner, Sensitivity and specificity of blood cobalt and chromium metal ions for predicting failure of metal-on-metal hip replacement, Bone Joint J. 93-B (2011) 13081313. doi:10.1302/0301-620X.93B10.26249.

[4] J.J. Jacobs, A.K. Skipor, P.A. Campbell, N.J. Hallab, R.M. Urban, H.C. Amstutz, Can metal levels be used to monitor metal-on-metal hip arthroplasties?, J. Arthroplasty. 19 (2004) 59-65. doi:10.1016/j.arth.2004.09.019.

[5] I.P. McAlister, M.P. Abdel, Elevated serum titanium level as a marker for failure in a titanium modular fluted tapered stem, Orthopedics. 39 (2016) e768-e770.

[6] H. von Schroeder, D. Smith, A. Gross, R. Piliar, R. Kandel, R. Chernecky, S. Lugowski, Titanemia From Total Knee Arthroplasty, J. Arthroplasty. 11 (1996) 620625 .

[7] R.M. Urban, J.J. Jacobs, M.J. Tomlinson, J. Gavrilovic, J. Black, M. Peoc'h, Dissemination of wear particles to the liver, spleen, and abdominal lymph nodes of patients with hip or knee replacement, J. Bone Joint Surg. Am. 82-A (2000) 457-476. http://www.ncbi.nlm.nih.gov/pubmed/10761937.

[8] I. Swiatkowska, N. Martin, A.J. Hart, Blood titanium level as a biomarker of orthopaedic implant wear, J. Trace Elem. Med. Biol. 53 (2019) 120-128. doi:10.1016/j.jtemb.2019.02.013.

[9] S.M. Kurtz, E. Lau, K. Ong, K. Zhao, M. Kelly, K.J. Bozic, Future young patient demand for primary and revision joint replacement: National projections from 2010 to 2030, Clin. Orthop. Relat. Res. 467 (2009) 2606-2612. doi:10.1007/s11999-009-08346.

[10] D.S. Casper, G.K. Kim, C. Restrepo, J. Parvizi, R.H. Rothman, Primary Total Hip Arthroplasty With an Uncemented Femoral Component. Five- to Nine-Year Results, J. Arthroplasty. 26 (2011) 838-841. doi:10.1016/j.arth.2011.02.010.

[11] M.M. Morlock, E.C. Dickinson, K.-P. Günther, D. Bünte, V. Polster, Head taper corrosion causing head bottoming out and consecutive gross stem taper failure in total hip arthroplasty, J. Arthroplasty. Xxx (2018) 1-10.

[12] J. Spanyer, J. Hines, C.M. Beaumont, J. Yerasimides, Catastrophic Femoral Neck Failure after THA with the Accolade®I Stem in Three Patients, Clin. Orthop. Relat. Res. 474 (2016) 1333-1338. doi:10.1007/s11999-015-4438-z.

[13] S.M. Kurtz, S.B. Kocagöz, J.A. Hanzlik, R.J. Underwood, J.L. Gilbert, D.W. MacDonald, G.C. Lee, M.A. Mont, M.J. Kraay, G.R. Klein, J. Parvizi, C.M. Rimnac, Do ceramic femoral heads reduce taper fretting corrosion in hip arthroplasty? A retrieval study, Clin. Orthop. Relat. Res. 471 (2013) 3270-3282. doi:10.1007/s11999013-3096-2.

[14] Z. Yi, Z. Bo, S. Bin, Y. Jing, Z. Zongke, P. Fuxing, Clinical Results and Metal Ion Levels After Ceramic-on-Metal Total Hip Arthroplasty: A Mean 50-Month Prospective Single-Center Study, J. Arthroplasty. 31 (2016) 438-441. doi:10.1016/j.arth.2015.09.034.

[15] P.-A. Vendittoli, A. Roy, S. Mottard, J. Girard, D. Lusignan, M. Lavigne, Metal ion release from bearing wear and corrosion with $28 \mathrm{~mm}$ and large-diameter metal-onmetal bearing articulations: a follow-up study, J. Bone Jt. Surgery-British Vol. 92-B (2010) 12-19.

[16] Eurachem Method Validation Working Group, The fitness for purpose of analytical 
methods a laboratory guide to method validation and related topics (Second Edition), 2014. doi:10.1016/S0014-2999(99)00500-2.

[17] D.W. Murray, R. Fitzpatrick, K. Rogers, H. Pandit, D.J. Beard, A.J. Carr, J. Dawson, The use of the Oxford hip and knee scores, J. Bone Joint Surg. Br. 89-B (2007) 10101014.

[18] Y. Kalairajah, K. Azurza, C. Hulme, S. Molloy, K.J. Drabu, Health outcome measures in the evaluation of total hip arthroplasties- a comparison between the harris hip score and the Oxford hip score, J. Arthroplasty. 20 (2005) 1037-1041.

[19] J. Dawson, R. Fitzpatrick, A. Carr, D. Murray, Questionnaire on the perceptions of patients about total hip replacement, J. Bone Joint Surg. Br. 78-B (1996) 185-190.

[20] V. Wylde, I. Learmonth, V. Cavendish, The Oxford hip score: the patient's perspective, Health Qual. Life Outcomes. 3 (2005) 1-8.

[21] P. Campbell, R. Urban, I. Catelas, A. Skipor, T. Schmalzried, Autopsy analysis thirty years after metal-on-metal total hip replacement, J. Bone Jt. Surg. 85 (2003) 22182222.

[22] J. Jacobs, A. Skipor, L. Patterson, N. Hallab, W. Paprosky, J. Black, J. Galante, Metal Release in Patients Who Have Had a Primary Total Hip Arthroplasty. A Prospective, Controlled, Longitudinal Study, J. Bone Jt. Surg. 80-A (1998) 1447-1458. doi:10.1016/0142-9612(85)90030-4.

[23] T.-K. Liu, S.-H. Liu, C.-H. Chang, R.-S. Yang, Concentration of metal elements in the blood and urine in the patients with cementless total knee arthroplasty, J. Exp. Med. 185 (1998) 253-262.

[24] L. Savarino, M. Greco, E. Cenni, L. Cavasinni, R. Rotini, N. Baldini, A. Giunti, Differences in ion release after ceramic-on-ceramic and metal-on-metal total hip replacement, J. Bone Joint Surg. Br. 88-B (2006) 472-476.

[25] L. Savarino, G. Padovani, M. Ferretti, M. Greco, E. Cenni, G. Perrone, F. Greco, N. Baldini, A. Giunti, Serum ion levels after ceramic-on-ceramic and metal-on-metal total hip arthroplasty: 8-Year minimum follow-up, J. Orthop. Res. 26 (2008) 1569-1576. doi:10.1002/jor.20701.

[26] A. Sarmiento-González, J.M. Marchante-Gayón, J.M. Tejerina-Lobo, J. Paz-Jiménez, A. Sanz-Medel, High-resolution ICP-MS determination of Ti, V, Cr, Co, Ni, and Mo in human blood and urine of patients implanted with a hip or knee prosthesis, Anal. Bioanal. Chem. 391 (2008) 2583-2589. doi:10.1007/s00216-008-2188-4.

[27] C.S. Muñiz, J.L. Fernández-Martin, J.M. Marchante-Gayón, J.I.G. Alonso, J.B. Cannata-Andía, A. Sanz-Medel, Reference values for trace and ultratrace elements in human serum determined by double-focusing ICP-MS, Biol. Trace Elem. Res. 82 (2001) 259-272. doi:10.1385/BTER:82:1-3:259.

[28] Y. Nuevo Ordóñez, M. Montes-Bayón, E. Blanco-González, J. Paz-Jiménez, J.M. Tejerina-Lobo, J.M. Peña-López, A. Sanz-Medel, Metal release in patients with total hip arthroplasty by DF-ICP-MS and their association to serum proteins, J. Anal. At. Spectrom. 24 (2009) 1037-1043. doi:10.1039/b820339c.

[29] P.-A. Vendittoli, A. Roy, S. Mottard, J. Girard, D. Lusignan, M. Lavigne, Metal ion release from bearing wear and corrosion with $28 \mathrm{~mm}$ and large-diameter metal-onmetal bearing articulations: A follow-up study, J. Bone Jt. Surg. - Br. Vol. 92-B (2010) 12-19. doi:10.1302/0301-620X.92B1.22226.

[30] G.W. Omlor, J.P. Kretzer, J. Reinders, M.R. Streit, T. Bruckner, T. Gotterbarm, P.R. Aldinger, C. Merle, In vivo serum titanium ion levels following modular neck total hip arthroplasty-10 year results in 67 patients, Acta Biomater. 9 (2013) 6278-6282. doi:10.1016/j.actbio.2012.12.001.

[31] B.R. Levine, A.R. Hsu, A.K. Skipor, N.J. Hallab, W.G. Paprosky, J.O. Galante, J.J. 
Jacobs, Ten-Year Outcome of Serum Metal Ion Levels After Primary Total Hip Arthroplasty, J. Bone Jt. Surg. 95 (2013) 512-518. doi:10.2106/JBJS.L.00471.

[32] W. Gofton, P.E. Beaule, Serum metal ions with a titanium modular neck total hip replacement system, J. Arthroplasty. 30 (2015) 1781-1786.

[33] D. Nam, J.A. Keeney, R.M. Nunley, S.R. Johnson, J.C. Clohisy, R.L. Barrack, Metal ion concentrations in young, active patients following total hip arthroplasty with the use of modern bearing couples, J. Arthroplasty. 30 (2015) 2227-2232.

[34] I. Swiatkowska, J.F.W. Mosselmans, T. Geraki, C.C. Wyles, J.J. Maleszewski, J. Henckel, B. Sampson, D.B. Potter, I. Osman, R.T. Trousdale, A.J. Hart, Synchrotron analysis of human organ tissue exposed to implant material, J. Trace Elem. Med. Biol. 46 (2018) 128-137. doi:10.1016/j.jtemb.2017.12.007.

[35] M. Goutam, C. Giriyapura, S. Mishra, S. Gupta, Titanium allergy: A literature review, Indian J. Dermatol. 59 (2014) 630. doi:10.4103/0019-5154.143526.

[36] E.J. Mcpherson, M. V Dipane, S.M. Sherif, Massive pseudotumor in a $28 \mathrm{~mm}$ ceramicpolyethylene revision THA: a case report, JISRF Reconstr. Rev. 4 (2014) 11-17.

[37] Y. Nuevo-Ordonez, M. Montes-Bayon, E. Blanco Gonzalez, A. Sanz-Medel, Y. Nuevo-Ordoñez, M. Montes-Bayón, E. Blanco González, A. Sanz-Medel, Titanium preferential binding sites in human serum transferrin at physiological concentrations., Met. Integr. Biometal Sci. 3 (2011) 1297-303. doi:10.1039/c1mt00109d.

[38] C.F. Harrington, C. Mckibbin, M. Rahanu, D. Langton, Titanium in hip replacement patients by Inductively Coupled Plasma Optical Emission Spectroscopy (ICP-OES), Ann. Clin. Biochem. 0 (2016) 1-8. doi:10.1177/0004563216662292.

[39] J. Versieck, The Collection and Preparation of Human-Blood Plasma or Serum for Trace-Element Analysis, J. Res. Natl. Bur. Stand. (1934). 91 (2012) 87. doi:10.6028/jres.091.014.

[40] J. Jacobs, A. Skipor, J. Black, R. Urban, J. Galante, Release and excretion of metal in patients who have a total hip-replacement component made of titanium-base alloy, J. Bone Jt. Surg. 73-A (1991) 1475-1486.

[41] J. Jacobs, A. Skipor, L. Patterson, N. Hallab, W. Paprosky, J. Black, J. Gallante, Metal release in patients who have had a primary total hip arthroplasty, J. Bone Jt. Surg. 80A (1998) 1447-1458.

[42] A. Weir, P. Westerhoff, L. Fabricius, K. Hristovski, N. Von Goetz, Titanium dioxide nanoparticles in food and personal care products, Environ. Sci. Technol. 46 (2012) 2242-2250. doi:10.1021/es204168d.

[43] D. Koller, P. Bramhall, J. Devoy, H. Goenaga-Infante, C.F. Harrington, E. Leese, J. Morton, S. Nuñez, J. Rogers, B. Sampson, J.J. Powell, Analysis of soluble or titanium dioxide derived titanium levels in human whole blood: consensus from an interlaboratory comparison, Analyst. (2018). doi:10.1039/C8AN00824H.

[44] K. Merritt, S.A. Brown, Storage and elimination of titanium, aluminum, and vanadium salts in vivo, J. Biomed. Mater. Res. 26 (1992) 1503-1515.

[45] S. Takai, N. Yoshino, Y. Kusaka, Y. Watanabe, Y. Hirasawa, Dissemination of metals from a failed patellar component made of titanium-base alloy, J. Arthroplasty. 18 (2003) 931-935. 
Appendix

Table A.1. Internal Quality Control results.

\begin{tabular}{|l|c|c|c|}
\hline \multicolumn{1}{|c|}{ IQC material } & $\begin{array}{c}\text { Mean } \\
\text { measured } \\
\text { concentration } \\
\left(\boldsymbol{\mu \mathbf { ~ L } ^ { - 1 } )}\right.\end{array}$ & $\begin{array}{c}\text { Manufacturer's } \\
\text { target }\left(\boldsymbol{\mu g} \mathbf{L}^{-\mathbf{1}}\right)\end{array}$ & $\begin{array}{c}\text { Bias to } \\
\text { manufacturer's } \\
\text { target }(\boldsymbol{\%})\end{array}$ \\
\hline ClinChek Plasma 1 & 11.5 & 12.4 & -6.9 \\
\hline ClinChek Plasma 2 & 49.3 & 47.3 & 4.2 \\
\hline Custom Whole Blood 1 & 0.6 & N/A & N/A \\
\hline Custom Whole Blood 2 & 10.7 & N/A & N/A \\
\hline
\end{tabular}

255

256

257

258

259

260

261

262

\begin{tabular}{|c|c|c|}
\hline Isotope & $\mathrm{Ti}^{47}$ & $\mathrm{Ga}^{71}$ \\
\hline Mass range & $46.948-46.954$ & $70.921-70.928$ \\
\hline Mass window & 50 & 40 \\
\hline Settling time & 0.300 & 0.050 \\
\hline Sample time & 0.7500 & 0.0500 \\
\hline Samples per peak & 25 & 20 \\
\hline Search window & 50 & 40 \\
\hline Integration window & 50 & 40 \\
\hline Scan type & EScan & EScan \\
\hline Resolution mode & Medium & Medium \\
\hline Runs & 4 & 4 \\
\hline Passes & 1 & 1 \\
\hline
\end{tabular}
bias of the submitted results compared to the assigned value is also shown.

Table A.3. Isotopes measured and ICP-MS settings used.

Table A.2. Results submitted by the laboratory to the Quebec Multielement External Quality Assessment Scheme (QMEQAS), the value assigned by QMEQAS, and the range considered acceptable by QMEQAS (See the QMEQAS participants manual for details). The percentage

\begin{tabular}{|c|c|c|c|c|}
\hline Sample & $\begin{array}{c}\text { Submitted results } \\
\left(\mathbf{n m o l ~ L} \mathbf{- 1}^{-1}\right)\end{array}$ & $\begin{array}{c}\text { Assigned value } \\
(\mathbf{n m o l ~ L}\end{array}$ & $\begin{array}{c}\text { Acceptable } \\
\text { range }\end{array}$ & Bias (\%) \\
\hline QM-B-Q1901 & 196 & 207 & $123-291$ & -5.3 \\
\hline QM-B-Q1902 & 319 & 307 & $181-433$ & +3.9 \\
\hline QM-B-Q1903 & 247 & 246 & $143-349$ & +0.4 \\
\hline
\end{tabular}

